\title{
Empirical Investigation of Omni-channel Customer Behavior: Multiple Mediation Effects of Website and Mobile Interactivity
}

\section{Hai Ninh Nguyen ${ }^{1}$ Thanh Ha Thi Le ${ }^{2}$}

${ }_{1,2}$ School of International Business and Economic, Foreign Trade University, Chua Lang, Dong Da, Ha Noi, Viet Nam.

Email:nguyen.haininh@ftu.edu.vn

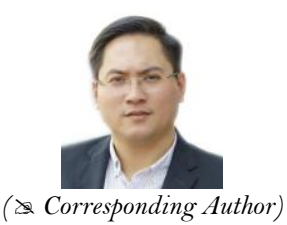

\section{Abstract}

While existing retail research has focused on retail channels in isolation from a single or multichannel retailing perspective, there is a need to investigate shopping behavioral intention from an omni-channel and customer-centric retailing perspective. The main of this study is to analyze the customer omni-channel behavior under multiple mediating effects of website and mobile interactivity. Data collected from valid 287 respondents via both online and paper form. Partial least squares structural equation modeling (PLS-SEM) and Smart-PLS software have been used to test proposed hypotheses. The result underlined the significant positive effects of technology literacy, attitude towards website interactivity and attitude towards mobile device interactivity on customer's behavioral intention. Moreover, website interactivity and augmented reality have highest impact attitude towards website interactivity and attitude towards mobile device interactivity respectively.

Keywords: Omnichannel customer behavior, Technology literacy, Mobile payment technology, Live pop-up chats, Augmented reality. JEL Classification: M10; M30; M37.

Citation | Hai Ninh Nguyen; Thanh Ha Thi Le (2021). Empirical Investigation of Omni-channel Customer Behavior: Multiple Mediation Effects of Website and Mobile Interactivity. Asian Journal of Social Sciences and Management Studies, 8(3): 69-76. History:

Received: 17 June 202

Revised: 20 July 2021

Accepted: 13 August 2021

Published: 3 September 202

Licensed: This work is licensed under a Creative Commons

Attribution 3.0 License $(\mathrm{cc})$ E

Publisher: Asian Online Journal Publishing Group
Acknowledgement: Both authors contributed to the conception and design of the study.

Funding: This study received no specific financial support

Competing Interests: The authors declare that they have no conflict of interests.

Transparency: The authors confirm that the manuscript is an honest, accurate, and transparent account of the study was reported; that no vital features of the study have been omitted; and that any discrepancies from the study as planned have been explained.

Ethical: This study follows all ethical practices during writing.

\section{Contents}

1. Introduction

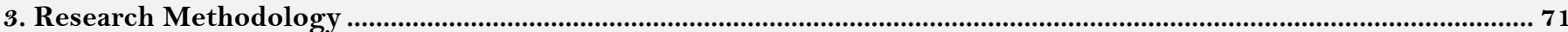

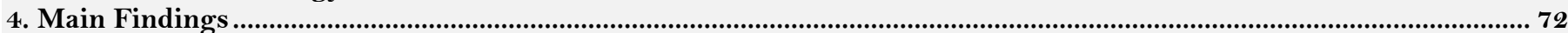

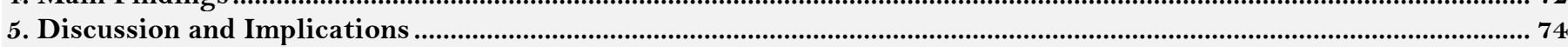

References 75 


\section{Contribution of this paper to the literature}

This paper contributes to the literature by underlining the impact of customer interactivity on website and mobile application on their behavior in omni-channel retail model. In which the technology literacy, mobile payment technology, live pop-up chats and Augmented reality have identified as the main antecedents.

\section{Introduction}

Omni-channel is an evolution of the multichannel customer approach, which has taken place over the last years across multiple industries (Lazaris \& Vrechopoulos, 2014; Verhoef, Kannan, \& Inman, 2015). An omni-channel approach aims to create a seamless customer experience regardless of where in the purchase process the consumer is or which channel is used (Piotrowicz \& Cuthbertson, 2014). Verhoef et al. (2015) provides one of the most wellcited definitions of an omni-channel approach; "the synergetic management of the numerous available channels and customer touchpoints, in such a way that the customer experience across channels and the performance over channels is optimized".

Through technology, retail firms may integrate all the information gathered through their different channels. This allows consumers to choose the most suiting channel for each situation in their interaction with the company and consumers increasingly seek out retailers that provide this type of seamless shopping experience. Scholars argue that technology has made omni-channel retailing inevitable with in-store technologies, augmented reality, location-based services and mobile devices integrating the offline channels with online channels in the retail environment (Lazaris, Vrechopoulos, Fraidaki, \& Doukidis, 2014). Omni-channel retailing has further enabled firms to interact with individual consumers at various touchpoints along the purchase process in a more unique way.

Previous cosmetics retail-related findings have shown that females have a more positive attitude and shop more frequently in contrast to males. Although these findings indicate that females are a key target market for cosmetics shopping, few studies have been explored from an omni-channel retail environment viewpoint. Since technology facilitates interactivity in the retail world, technology is an important feature of this study. Interestingly, research concerning the impact of technology advancement in the context of cosmetics in an omni-channel retail environment has not yet been investigated. Nor has the possibility of a relationship between technology investment and omni-channel retailing. With relevance to literature based on interactivity, some studies have established a link between value and interactivity, while other studies have not. More importantly, the levels of interactivity have scarcely been researched and because shoppers respond differently to different types of technology, the application of these themes to an omni-channel retail environment would produce significant findings.

\section{Literature Review}

\subsection{Customer Omnichannel Beahviors}

"Behavioral intentions are instructions that people give to themselves to behave in certain ways" (Triandis, 1980). They are people's decisions to perform particular actions. Intentions can be inferred from participants' responses that have the form, "I intend to do X", "I plan to do X', or "I will do X'. In psychological terms, a behavioral intention indexes a person's motivation to perform a behavior. That is, behavioral intentions encompass both the direction (to do X vs. not to do X) and the intensity (e.g., how much time and effort the person is prepared to expend in order to do $\mathrm{X}$ ) of a decision. The intention construct lies at the heart of theories of attitude-behavior relations and models of health-related behavior. According to the theory of reasoned action, intentions are the proximal predictors of behavior and mediate the influence of both the theory's predictors (attitudes and subjective norms) and extraneous variables (e.g., personality) on behavior. Likewise, protection motivation theory assumes that behavioral intentions mediate the relationship between the putative predictors (threat appraisal and coping appraisal) and behavior.

The theory of planned behavior also assumes that intentions are the most important predictor of behavior but acknowledges that people may not always have sufficient control over performing the behavior to enact their intentions (Ajzen, 1985, 1991). Similarly, Triandis (1980) suggests that "low facilitating conditions" could prevent performance of an intended behavior. Triandis (1980) also points out that certain behaviors are more likely to be controlled by "habits" than by conscious intentions. In this case, we are yet to identify the behavior of customers buying cosmetics products. Instead, we are trying to determine how intentional behavior is affected by attitudes towards different channel interactivity.

\subsection{Technology Literacy}

Searching for the term Technology literacy is always related to Information and Communication Technology (ICT). Markauskaite (2006) suggests that technological literacy is part of ICT literacy that falls into the category of inter-literacy perspectives including the ability to use ICT as an integral part of basic literacy. Maryl and Technology Education State Curriculum suggests that technology literacy is the ability to use, understand, regulate and assess an innovation that involves processes and knowledge to solve problems and expand one's abilities. According to the National Academy of Engineering and the National Research Council of The National Academics, literacy technology is an understanding of technology at a level that enables effective use in modern technology which consists of three main components, namely knowledge, ability and critical thinking, and decisionmaking. Based on the above definition, technology literacy can be interpreted as an ability that consists of aspects of science, critical thinking skills, and decision-making in an effort to effectively utilize technology/innovation of human works. Under the realm of omnichannel retailing which utilizes technology to enhance customer's seemless experience, technology literacy play a crucial role in determining both customer's attitude towards interactivity in different channels and customer's behavioral intention in general. For such reasons, the hypotheses were developed as below:

- H1: There is significant effect of technology literacy (TE) on behavioral intention (BEH).

- H2: There is significant effect of technology literacy (TE) on attitude towards website interactivity (AWI). 
- H3: There is significant effect of technology literacy (TE) on attitude towards mobile device interactivity (AMI).

2.3. Interactivity at Omnichannel's POS - Website Channel

As a retail channel, online retailing which use Internet-based technology is useful for improving the persuasion and comprehension competencies of websites. For this particular POS, the author chooses three main factor affecting customer's interactivity which are (1) website atmospherics, (2) live pop-up chats, (3) technology excellence.

\subsubsection{Website Atmospherics}

The classification of the atmospherics cues of a virtual shopping outlet into three groups: the structural factors, the atmospheric factors and the social factors. Thus, navigation features (easiness of navigation, the internal search engine, the organization of menus and website structure and layouts) become the structural factors. Whereas, the design characteristics, that affect the e-customers' senses and shape their emotional states (music, color, videos, light, odor, entertainment, text and images), are associated with the atmospheric factors. As for the social factors, they are presented by the overall environment agents (Baker, Parasuraman, Grewal, \& Voss, 2002).

\subsubsection{Live Pop-Up Chats}

A live pop-up chat is a communicative tool that allows for a two-way dialogue to be created. The way it works is that a message bar will "pop up" at the bottom of the user's screen when a retailer's online store is visited and real salespeople will greet, address and assist consumers with their enquiries and problems via an "online chat" that takes place in real time. What is understood is that interactivity over the Internet allows consumers to actively partake in the persuasion process, as users are able to control the messages they are exposed to in mediated environments (Song \& Zinkhan, 2008; Stewart \& Pavlou, 2002). Users are also able to choose and, therefore, have control over the content, time and communication act that they participate in (Li, Daugherty, \& Biocca, 2002). This is known as active control. Users achieve active control when they are more cognitively involved in an interactive online activity, which then generates engagement as it allows users to communicate in real-time (Cho \& Leckenby, 1999; Liu \& Shrum, 2002; McMillan, 2000; Stewart \& Pavlou, 2002). Thus, the study proposes the following hypotheses:

- H4: There is significant effect of attitudes towards website interactivity (AWI) on behavioral intention (BEH).

- H5: There is significant effect of website atmospherics (WAT) on attitude towards website interactivity (AWI).

- H6: There is significant effect of live pop-up chats (LPC) on attitude towards website interactivity (AWI).

\subsection{Interactivities at POS - Mobile Device Channel}

The development of new digital and more specifically, mobile channel has led to the consideration of smartphones as a separate sales channel. At this POS, the research mainly focuses on 2 separate factors for interactivity which are (1) mobile payment technology and (2) augmented reality.

\subsubsection{Mobile Payment Technology}

Mobile payments commonly provide access to account-based funds, such as account transfers, direct online banking, debit or credit cards. The typical usage entails the user choosing to make a mobile payment, connecting to a server via the mobile device to perform authentication and authorization, and subsequently, the user is presented with confirmation of the complete transaction. A mobile payment service comprises of all technologies that are offered to the user as well as all the tasks that the payment service providers perform to commit payment transactions (Rushabh, 2015). When we consider mobile payment technology at a POS which is mobile device, this method enables the consumer to pay for goods or services using their mobile device. Overall, existing research concerning the effects of mobile payment technology is limited and this exposes a need to investigate this technology further and in an omni-channel retail environment.

\subsubsection{Augmented Reality}

Augmented reality (AR) is defined as "a real-time direct or indirect view of a physical real-world environment that has been enhanced/augmented by adding virtual computer-generated information to it Carmigniani et al. (2011). AR technology is increasingly adopted by marketers as a tool of product display. AR based product display enables consumers to engage in computer-mediated communication and interact with the interface, which increase perceived interactivity. Research has examined that perceived interactivity can further impact satisfaction, immersion, attitude of consumer (Hoffman \& Novak, 2009; Song \& Zinkhan, 2008). Huang and Liao (2015) concluded that, AR allows the user to interact with the virtual images using real objects in a seamless way. In this way, AR based display aligns real and virtual objects with each other in real time, which offers consumers both utilitarian and hedonic values and thus may enhance consumers' attitudes towards the product displayed.

- H7: There is significant effect of attitude towards mobile device interactivity (AMI) on behavioral intention (BEH).

- H8: There is significant effect of mobile payment technology (MPT) on attitude towards mobile device interactivity $(A M I)$.

- H9: There is significant effect of augmented reality (AUR) on attitude towards mobile device interactivity (AMI).

\section{Research Methodology}

This study attempts to identify the influential factors concerned with attitude towards website interactivity and attitude towards mobile device interactivity on customer's behavioral intention towards cosmetics product. The research aim at the customers who have used L'oreal's cosmetics products. To conduct the survey, we co-operated with Hanoi SME association to do surveying with employees working in their members. Primary data was collected through 2 ways: direct interview at L'oreal cosmetics physical stores and online investigation through 
Facebook group from December 2020 to February 2021. The demographical variables such as age, gender, educational level was used to be moderating variables.

A pre-test of questionnaire was conducted in December 2020 with 50 customers of different demographic traits and shopping channels. After collecting the pre-test data, the questionnaire was edited and adjusted to fit with the real condition.

The collected data was analyzed Smart PLS 3.3.3 software program.

\subsection{Sample Selection}

The total population of this study is customers buying L'oreal cosmetics products in different channels of omni channel retailing in Hanoi city. There were around 100 people who were directly interviewed and 300 people who reply by Google form in total of 400 surveyors. After elimination of cases having incomplete data and outliners, the final sample was 287 valid sampling unit for a total response rate of $71.75 \%$.

Table 1 provides the demographical profile of the respondents. Most respondents in the study were female (76,3\%); the two highest percentage of respondents' age are $26-35$ and $<25$ with $41.1 \%$ and $25,4 \%$ respectively. The results of descriptive statistics also indicated that a large percentage of respondents has highest educational level of bachelor $(58,9 \%)$.

\begin{tabular}{l|c|c|c}
\multicolumn{4}{c}{ Table-1. Demographical profile of the respondents $(\mathrm{n}=287)$. } \\
\hline Demographic variables & Category & Frequency & Percentage (\%) \\
\hline \multirow{4}{*}{ Gender } & Male & 26 & $9.1 \%$ \\
\cline { 2 - 4 } & Female & 219 & $76.3 \%$ \\
\cline { 2 - 4 } & LGBT & 42 & $14.6 \%$ \\
\cline { 2 - 4 } Age & $<25$ & 73 & $25.4 \%$ \\
\cline { 2 - 4 } & $26-35$ & 118 & $41.1 \%$ \\
\cline { 2 - 4 } & $36-45$ & 41 & $14.3 \%$ \\
\hline \multirow{4}{*}{ Educational level } & $>45$ & 55 & $19.2 \%$ \\
\cline { 2 - 4 } & High school or lower & 20 & $7 \%$ \\
\cline { 2 - 4 } & Undergraduate & 42 & $14.6 \%$ \\
\cline { 2 - 4 } & Bachelor & 169 & $58.9 \%$ \\
\cline { 2 - 4 } & Master or higher & 56 & $19.5 \%$ \\
\hline
\end{tabular}

\subsection{Measurements}

The level of which each independent variable affects behavioral intention is measured from 1 (least effect) to 5 (greatest effect) as interval scale of Likert. The measurement will have 5 scale: 1 - Totally disagree, 2- Disagree, 3Neutral, 4- Agree, 5- Totally agree. The variables include: (1) Behavioral intention; (2) technology literacy; (3) Attitude towards website interactivity; (4) Attitude towards mobile device interactivity; (5) Website atmospherics; (6) Live pop-up chats, (7) Mobile payment technology and (8) Augmented reality (Appendix 1).

\subsection{Data Analysis Procedure}

This study used the Smart PLS to conduct descriptive statistics and inferential statistical techniques as: Factor analysis and structural equation modeling. The structural equation modeling (SEM) was conducted to identify the influential factors that may affect the behavioral intention of customer towards cosmetics product. In terms of analysis, Anderson and Gerbing (1988) stated that PLS - SEM is a two-step process involving assessment of the measurement and structural model. First, the measurement model was assessed by examining the Cronbach anpha (CA), internal composite reliability (CR), convergent validity (CV) and discriminant validity (DV) (Hair Jr, Sarstedt, Ringle, \& Gudergan, 2017).

\section{Main Findings}

The study is carried on by applying PLS-SEM technique for development of theoretical model and consequently the findings and the interpretation among the variables have been conducted accordingly. The data analysis was performed by SmartPLS 3.3.3. According to Urbach and Ahlemann (2010) PLS- SEM can be applied to the analysis of non-normally distributed data, does not demand a large sample size, and serves the purposes of exploratory study rather than theory testing. Besides, Worthington and Whittaker (2006) argued that PLS-SEM is more suitable than CB-SEM for theory development in the case of the number of valid cases fewer than the minimum required sample size - 300. Thus, with the number of 287 valid cases, PLS-SEM is properly applied to this study. Along with the instruction of conducting and reporting PLS-SEM analysis (Hair, Risher, Sarstedt, \& Ringle, 2019) suggested 2 main steps: (1) evaluation of the measurement models and (2) the structural model.

\subsection{Measurement Models}

To satisfy convergent validity, indicator outer loading should exceed 0.70 and both indicator reliability and average variance extracted (AVE) should be higher than 0.50. Discriminant validity was assessed by the FornellLarcker criterion and cross-loadings. The square root of AVE of each latent construct should be higher than the ecorrelations with other latent constructs based on the Fornell-Larcker criterion. In addition, an indicator's outer loading on the associated construct should be higher than its cross loadings with all other constructs (Hair Jr et al., 2017). Composite reliability and Cronbach's alphas between 0.60 and 0.70 indicate acceptable internal consistency in exploratory research, with values between 0.70 and 0.90 indicating satisfactory to good reliability (Hair et al., 2019).

From the analysis result, it was found that the behavioral intention construct would be reliable and valid after deleting 1 item (WAT1) from website atmospherics construct with the outer loadings equal to or less than 0.07. All the rest 24 items have satisfactory levels of convergent validity and reliability with outer loadings $>0.70$ (significant); indicator reliability $>0.50$ (good) and AVE $>0.50$ (acceptable). The composite reliability and CR 
value of 8 factors have range from 0.817 to 1 . The BEH met the evaluation criteria of discriminant validity based on the Fornell-Larcker criterion and higher outer loadings, eight factors showed the different from each other and no construct is represented by other constructs in the model Table 2.

Table-2. Internal Consistency Reliability and Convergent Validity.

\begin{tabular}{l|c|c|c|c|c}
\hline \multicolumn{1}{c}{ Table-2. Internal Consistency Reliability and Convergent Validity. } & CR & AVE \\
\hline Constructs & Measurement item & Factor Loadings & CA & CR \\
\hline Augmented reality & AUR $(3$ items) & $0.835-0.860$ & 0.799 & 0.882 & 0.713 \\
\hline Live pop-up chats & LPC $(5$ items) & $0.729-0.836$ & 0.848 & 0.892 & 0.623 \\
\hline Mobile payment technology & MPT $(5$ items $)$ & $0.747-0.820$ & 0.857 & 0.897 & 0.637 \\
\hline Technology literacy & TE $(4$ items $)$ & $0.777-0.827$ & 0.814 & 0.817 & 0.642 \\
\hline Website atmospherics & WAT $(5$ items $)$ & $0.743-0.860$ & 0.845 & 0.896 & 0.684 \\
\hline
\end{tabular}

Note: All item loadings are significant at .001 $(\mathrm{p}<.001)$. CA = Cronbach's anpha, AVE = Average variance extracted, CR $=$ composite reliability. WAT1 was deleted due to low factor loadings.

To depict the extent to which a construct is truly distinct from other constructs by empirical standards, Hair Jr et al. (2017) suggested the discriminant validity. Henseler, Ringle, and Sarstedt (2015) suggested the HeterotraitMonotrait ratio of correlations (HTMT) approach to determine the discriminant validity of the constructs. In order to achieve the discriminant validity, the HTMT value should not be greater than the HTMT.85 value of 0.85 (Clark, Watson, \& Reynolds, 1995; Kline, 2011) or the HTMT.90 value of 0.90 (Gold, Malhotra, \& Segars, 2001; Teo, Srivastava, \& Jiang, 2008). Moreover, Fornell and Larcker (1981) stated that for each variable, the square roots of the AVE should be greater than any of the correlations involving the said variable. Therefore, study use the square roots of AVE coefficients to measure the validity of constructs. The results of Table 3 indicate that the measures used in this research have discriminant validity.

Table-3. Discriminant Validity.

\begin{tabular}{l|l|l|l|l|l}
\hline & AUR & LPC & MPT & TE & WAT \\
\hline AUR & 0.845 & & & & \\
\hline LPC & 0.299 & 0.789 & & & \\
\hline MPT & 0.422 & 0.413 & 0.798 & & \\
\hline TE & 0.219 & 0.253 & 0.218 & 0.801 & \\
\hline WAT & 0.411 & 0.415 & 0.488 & 0.195 & 0.827 \\
\hline
\end{tabular}

To examine the multicollinearity, study use the Variance Inflation factors (VIF). A VIF value greater than 5 indicates the multicollinearity (Hair, Sarstedt, Hopkins, \& Kuppelwieser, 2014). The analysis results show that the lowest VIF value is 1.000 and the highest value is 2.236 lower than 5 that indicating no multicollinearity issue.

\subsection{Structural Models}

Structural model was assessed to test the three causal relationships: (1) between attitude towards website interactivity, attitude towards mobile device interactivity and behavioral intention; (2) between technology literacy and attitude towards website interactivity, attitude towards mobile device interactivity, behavioral intention, (3) between attitude towards website interactivity and live pop-up chats, website atmospherics, technology literacy and (4) between attitude towards mobile device interactivity and mobile payment technology, augmented reality, technology literacy

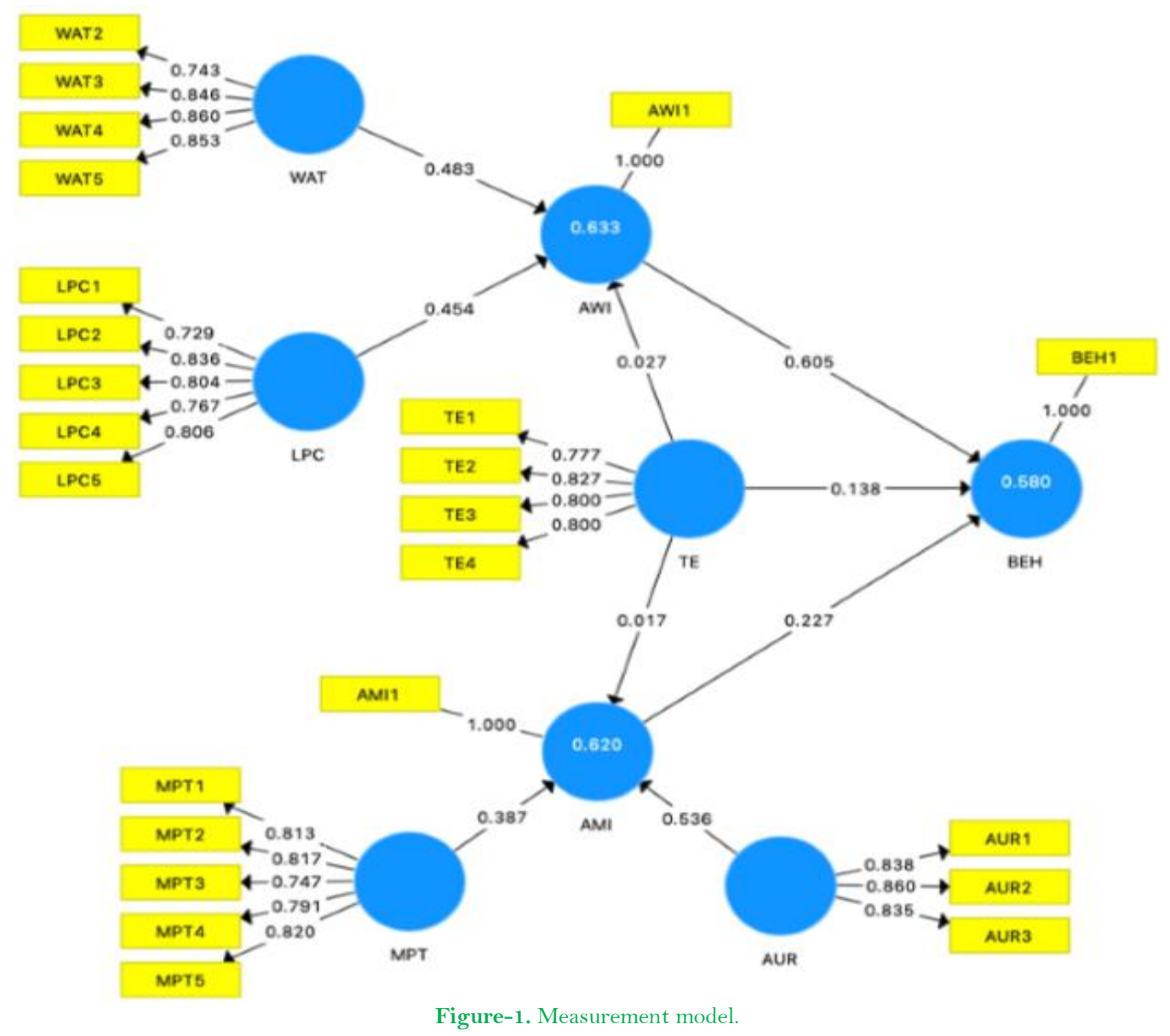


Hair et al. (2014) stated the coefficient of determination ( $R^{2}$ values) and path coefficient ( $\beta$ values) were parameters to determine how well the data supported the hypothesized relationships. A bootstrapping process with 5000 interactions was performed to generate t-values and standard errors to confirm the statistical significance. In which, R2 is used to measure the predictive accuracy of the model and by Gronemus et al. (2010), R2 represents the percentage of variance in the dependent variables as explained by the independent variables in the model. The path coefficients ( $\beta$ values) indicate the degree of change in the dependent variable for each independent variable (Gronemus et al., 2010; Pallant \& Tennant, 2007). Along with $R^{2}$, the effect size $\left(f^{2}\right)$ and predictive relevance $\left(q^{2}\right)$ for each path can be considered as weak to large effect (Hair Jr et al., 2017). The effect size $f^{2}$ measures the changes in $\mathrm{R}^{2}$ when a specific exogenous variable is excluded from the model and evaluate whether substantial changes occur in the endogenous latent variable. Cohen (1988) gives the guidelines to assess the $f^{2}$ whereby $0.02,0.15$ and 0.35 indicate small, medium and large effects, respectively. Hair et al. (2014) suggested using the Blindfolding (a sample reuse technique that omits every $d$ th data point in the indicators of the endogenous constructs) to assess the $q^{2}-$ predictive relevance. The $q^{2}$ value larger than o indicates that model has predictive relevance for a certain dependent construct (Akter, D'ambra, \& Ray, 2011). Moreover, the model fit was assessed by using SRMR. Due to Hair Jr et al. (2017) the SRMR value below 0.10 indicating the acceptable model fit.

The results of Table 4 and Figure 1 show that the path coefficients for the relationships that were statistically significant due to $p$ values $<0.05$. However, since the $\mathrm{p}$ values of 2 relationships $>0.05$ (TE $\rightarrow$ AMI, TE $\rightarrow$ AWI) the relationship were not statistically significant and hence are not supported.

\begin{tabular}{l|l|c|c|c|c|c|c}
\hline \multicolumn{7}{c}{ Table-4. Hypotheses testing. } \\
\hline Hypotheses & Path & O & M & STDEV & T & P & Decision \\
\hline H1 & TE $\rightarrow$ BEH & 0.138 & 0.139 & 0.041 & 3.352 & 0.001 & Supported \\
\hline H4 & AWI $\rightarrow$ BEH & 0.605 & 0.607 & 0.044 & 13.865 & 0.000 & Supported \\
\hline H5 & WAT $\rightarrow$ AWI & 0.483 & 0.483 & 0.043 & 11.176 & 0.000 & Supported \\
\hline H6 & LPC $\rightarrow$ AWI & 0.454 & 0.453 & 0.050 & 9.003 & 0.000 & Supported \\
\hline H7 & AMI $\rightarrow$ BEH & 0.227 & 0.226 & 0.053 & 4.280 & 0.000 & Supported \\
\hline H8 & MPT $\rightarrow$ AMI & 0.387 & 0.388 & 0.054 & 7.198 & 0.000 & Supported \\
\hline H9 & AUR $\rightarrow$ AMI & 0.536 & 0.536 & 0.033 & 16.325 & 0.000 & Supported \\
\hline
\end{tabular}

As shown in Table 5, attitude towards mobile device interactivity and attitude towards website interactivity can be explained around $58 \%$ of variance explained of behavioral intention $\left(R^{2}=0.580\right)$, whereas $62 \%$ of variance of attitude towards mobile device interactivity explained by website interactivity, live pop-up chats and technology literacy $\left(R^{2}=0.620\right)$. In addition, $63.3 \%$ variance for attitude towards website interactivity was explained by mobile payment technology, augmented reality and technology literacy $\left(R^{2}=0.633\right)$. Moreover, the three $R^{2}$ values are over 0.1 , thus the predictive capability is established. In order to assess the predictive relevance, we examine the $q^{2}$ values. The results show that all $q^{2}$ values of $0.571,0.594$ and 0.610 exceed 0 representing that the behavioral intention, attitude towards mobile device interactivity and attitude towards website interactivity demonstrating acceptable predictive relevance. Additionally, the SRMR value is $0.068<0.10$ that indicates the acceptable model fit

\begin{tabular}{|c|c|c|c|}
\hline & $\mathbf{R 2}$ & $\mathbf{q 2}$ & SMRM \\
\hline Behavioral intention & 0.580 & 0.571 & \multirow{3}{*}{0.068} \\
\hline Attitude towards mobile device interactivity & 0.620 & 0.594 & \\
\hline Attitude towards website interactivity & 0.633 & 0.610 & \\
\hline
\end{tabular}

\section{Discussion and Implications}

The study utilized PLS-SEM to investigate the relationships of 8 variables: behavioral intention, attitude towards mobile device interactivity, attitude towards website interactivity, website atmospherics, live pop-up chats, mobile payment technology, augmented reality and technology literacy. The findings indicate that attitude towards website interactivity has the most significant effect on behavioral intention towards cosmetics product in omnichannel retail environments (H4). This indicates that in order for customer to intentionally behave positively when buying L'oreal cosmetics products, they firstly need to have positive attitudes (dominant, enjoyable, satisfied, ...) especially in the website environment. The variable technology literacy and attitude towards mobile device interactivity were proven to also have positive effect on behavioral intention even though the impact is relatively small compared to attitude towards website interactivity.

Regarding the indirect effect, the structured model confirmed other relationships that website atmospherics and live pop-up chats have positive influence on attitude towards website interactivity (H5, H6). Technology literacy seems to have no significant effect on this variable. Specifically, among two kinds of interactivities, the website atmospherics plays the most important role, then the live pop-up chats. This is quite correct since cosmetics products are purchased a lot through e-commerce platforms nowadays. One of the most popular platforms in Vietnam is Shopee, which has good user interface and other mentioned website atmospherics.

The current study also reveals that mobile payment technology and augmented reality having positive impacts on attitude towards mobile device interactivity (H8, H9). Technology literacy was found to have very little effect on attitude towards mobile device interactivity. Between mobile payment technology and augmented reality, the augmented reality has much larger effect than the mobile payment technology. This is quite interesting because augmented reality is a new concept in Vietnam market. By looking at the great advantages augmented reality brings to customers, we can affirm that this technology has a lot for retailers to cultivate in the near future.

There are some managerial implications that enterprises can apply to enhance customers' attitude in different points of sale and most importantly, increase customers' behavioral intention to purchase cosmetics products. In 
the short run, retailers or enterprises can focus on website interactivity first since it would bring instant and significant change to the overall behavioral intention of customers.

\section{References}

Ajzen, I. (1985). From intentions to actions: A theory of planned behavior. In Action control (pp. 11-39). Berlin, Heidelberg: Springer

Ajzen, I. (1991). The theory of planned behavior. Organizational Behavior and Human Decision Processes, 50(2), $179-211$.

Akter, S., D'ambra, J., \& Ray, P. (2011). An evaluation of PLS based complex models: The roles of power analysis, predictive relevance and GoF index. Paper presented at the Proceedings of the 17th Americas Conference on Information Systems (AMCIS2011). 1-7. Detroit, USA: Association for Information Systems.

Anderson, J. C., \& Gerbing, D. W. (1988). Structural equation modeling in practice: A review and recommended two-step approach. Psychological Bulletin, 103(3), 411-423. Available at: https://doi.org/10.1037/0033-2909.103.3.411.

Baker, J., Parasuraman, A., Grewal, D., \& Voss, G. B. (2002). The influence of multiple store environment cues on perceived merchandise value and patronage intentions. Journal of Marketing, 66(2), 120-141. Available at: https://doi.org/10.1509/jmkg.66.2.120.18470.

Carmigniani, J., Furht, B., Anisetti, M., Ceravolo, P., Damiani, E., \& Ivkovic, M. (2011). Augmented reality technologies, systems and applications. Multimedia Tools and Applications, 51(1), 341-377.

Cho, C. H., \& Leckenby, J. D. (1999). Interactivity as a measure of advertising effectiveness: Antecedents and consequences of interactivity in web advertising. Paper presented at the Proceedings of the Conference-American Academy of Advertising. American Academy of Advertising.

Clark, L. A., Watson, D., \& Reynolds, S. (1995). Diagnosis and classification of psychopathology: Challenges to the current system and future directions. Annual Review of Psychology, 46(1), 12 1-153. Available at: https://doi.org/10.1 146/annurev.ps.46.020195.001005.

Cohen, J. (1988). Set correlation and contingency tables. Applied Psychological Measurement, 12(4), 425-434. Available at: https://doi.org/10.1177/014662168801200410.

Fornell, C., \& Larcker, D. F. (1981). Evaluating structural equation models with unobservable variables and measurement error. Journal of Marketing Research, 18(1), 39-50. Available at: https://doi.org/10.1177/002224378101800104.

Gold, A. H., Malhotra, A., \& Segars, A. H. (2001). Knowledge management: An organizational capabilities perspective. Journal of Management Information Systems, 18(1), 185-2 14. Available at: https://doi.org/10.1080/0742 1222.2001.11045669.

Gronemus, J. Q., Hair, P. S., Crawford, K. B., Nyalwidhe, J. O., Cunnion, K. M., \& Krishna, N. K. (2010). Potent inhibition of the classical pathway of complement by a novel C1q-binding peptide derived from the human astrovirus coat protein. Molecular Immunology, 48(1-3), 305-313. Available at: https://doi.org/10.1016/j.molimm.2010.07.012.

Hair, J. F., Risher, J. J., Sarstedt, M., \& Ringle, C. M. (2019). When to use and how to report the results of PLS-SEM. European Business Review, 31(1), 2-24. Available at: https://doi.org/10.1108/ebr-11-2018-0203.

Hair Jr, J. F., Sarstedt, M., Ringle, C. M., \& Gudergan, S. P. (2017). Advanced issues in partial least squares structural equation modeling: Sage Publications.

Hair, J., J. F., Sarstedt, M., Hopkins, L., \& Kuppelwieser, V. G. (2014). Partial least squares structural equation modeling (PLS-SEM): An emerging tool in business research. European Business Review, 26(2), 106-121. Available at: https://doi.org/10.1108/ebr-10-20130128.

Henseler, J., Ringle, C. M., \& Sarstedt, M. (2015). A new criterion for assessing discriminant validity in variance-based structural equation modeling. Journal of the Academy of Marketing Science, 43(1), 115-135. Available at: https://doi.org/10.1007/s1 1747-014-0403-8.

Hoffman, D. L., \& Novak, T. P. (2009). Flow online: Lessons learned and future prospects. Journal of Interactive Marketing, 23(1), 23-34. Available at: https://doi.org/10.1016/j.intmar.2008.10.003.

Huang, T.-L., \& Liao, S. (2015). A model of acceptance of augmented-reality interactive technology: The moderating role of cognitive innovativeness. Electronic Commerce Research, 15(2), 269-295. Available at: https://doi.org/10.1007/s 10660-014-9163-2.

Kline, R. B. (2011). Convergence of structural equation modeling and multilevel modeling: The Sage hanbook of Innovation in Social research method: Sage Publications.

Lazaris, C., \& Vrechopoulos, A. (2014). From multichannel to "omnichannel" retailing: Review of the literature and calls for research. Paper presented at the 2nd International Conference on Contemporary Marketing Issues,(ICCMI).

Lazaris, C., Vrechopoulos, A., Fraidaki, K., \& Doukidis, G. (2014). Exploring the "Omnichannel" shopper behaviour. Paper presented at the AMA SERVSIG, International Service Research Conference.

Li, H., Daugherty, T., \& Biocca, F. (2002). Impact of 3-D advertising on product knowledge, brand attitude, and purchase intention: The mediating role of presence. Journal of Advertising, 31(3), 43-57. Available at: https://doi.org/10.1080/00913367.2002.10673675.

Liu, Y., \& Shrum, L. J. (2002). What is interactivity and is it always such a good thing? Implications of definition, person, and situation for the influence of interactivity on advertising effectiveness. Journal of Advertising, 31(4), 53-64. Available at: https://doi.org/10.1080/00913367.2002.10673685.

Markauskaite, L. (2006). Gender issues in preservice teachers' training: ICT literacy and online learning. Australasian Journal of Educational Technology, 22(1), 1-20. Available at: https://doi.org/10.14742/ajet.1304.

McMillan, S. J. (2000). The microscope and the moving target: The challenge of applying content analysis to the World Wide Web. Journalism \& Mass Communication Quarterly, 77(1), 80-98. Available at: https://doi.org/10.1177/107769900007700107.

Pallant, J. F., \& Tennant, A. (2007). An introduction to the Rasch measurement model: An example using the hospital anxiety and depression scale (HADS). British Journal of Clinical Psychology, 46(1), 1-18. Available at: https://doi.org/10.1348/014466506x96931.

Piotrowicz, W., \& Cuthbertson, R. (2014). Introduction to the special issue information technology in retail: Toward omnichannel retailing. International Journal of Electronic Commerce, 18(4), 5-16. Available at: https://doi.org/10.2753/jec 1086-4415180400.

Rushabh, P. (2015). Comparative review of existing mobile payment systems. International Journal of Applied Engineering Research, 10(7), 16873-16884.

Song, J. H., \& Zinkhan, G. M. (2008). Determinants of perceived web site interactivity. Journal of Marketing, 72(2), 99-113. Available at: https://doi.org/10.1509/jmkg.72.2.99.

Stewart, D. W., \& Pavlou, P. A. (2002). From consumer response to active consumer: Measuring the effectiveness of interactive media. Journal of the Academy of Marketing Science, 30(4), 376-396. Available at: https://doi.org/10.1 177/009207002236912.

Teo, T. S., Srivastava, S. C., \& Jiang, L. (2008). Trust and electronic government success: An empirical study. Journal of Management Information Systems, 25(3), 99-132. Available at: https://doi.org/10.2753/mis0742-1222250303.

Triandis, H. C. (1980). Reflections on trends in cross-cultural research. Journal of Cross-Cultural Psychology, 11(1), 35-58. Available at: https://doi.org/10.1177/0022022180111003.

Urbach, N., \& Ahlemann, F. (2010). Structural equation modeling in information systems research using partial least squares. Journal of Information Technology Theory and Application, $11(2), 5-40$.

Verhoef, P. C., Kannan, P. K., \& Inman, J. J. (2015). From multi-channel retailing to omni-channel retailing: Introduction to the special issue on multi-channel retailing. Journal of Retailing, 91(2), 174-181. Available at: https://doi.org/10.1016/j.jretai.2015.02.005.

Worthington, R. L., \& Whittaker, T. A. (2006). Scale development research: A content analysis and recommendations for best practices. The Counseling Psychologist, 34(6), 806-838. Available at: https://doi.org/10.1177/0011000006288127. 


\begin{tabular}{|c|c|}
\hline \multicolumn{2}{|c|}{ Behavioral intentions - BEI } \\
\hline BEI 1 & I intent to continue using L'oreal cosmetics products in the future \\
\hline \multicolumn{2}{|c|}{ Website atmospherics - WAT } \\
\hline WAT1 & The color is very well-blended \\
\hline WAT2 & The pictures of product are visually appealing \\
\hline WAT3 & The fonts are easy to read \\
\hline WAT4 & Background music is pleasant \\
\hline WAT5 & Product presentation is useful \\
\hline \multicolumn{2}{|c|}{ Live pop-up chats - LPC } \\
\hline LPC1 & Live pop-up chats give me instant answers \\
\hline $\mathrm{LPC} 2$ & Live pop-up chats give me useful information \\
\hline LPC3 & Live pop-up chat is easy to use \\
\hline $\mathrm{LPC} 4$ & Live pop-up chats make me feel in control of conversation \\
\hline LPC5 & Live pop-up chats allow me to do different tasks at the same time \\
\hline \multicolumn{2}{|c|}{ Online product reviews - OPR } \\
\hline OPR 1 & Online product review is useful to me \\
\hline OPR2 & Online product review gives me abundant information about product \\
\hline OPR3 & Online product review helps me compare different products' prices \\
\hline $\mathrm{OPR} 4$ & Online product review helps me compare different products' quality \\
\hline \multicolumn{2}{|c|}{ Mobile payment technology - MPT } \\
\hline MPT1 & Mobile payment technology allows me to have continuous shopping experience \\
\hline MPT2 & Mobile payment technology is innovative \\
\hline MPT3 & Mobile payment technology is useful \\
\hline MPT4 & Mobile payment technology is easy to use \\
\hline MPT5 & Mobile payment technology is safe to use \\
\hline \multicolumn{2}{|c|}{ Augmented reality - AUR } \\
\hline AUR1 & Augmented reality reflects the movement correctly when I move the product \\
\hline AUR2 & $\begin{array}{l}\text { Augmented reality helps me to visualize how it will be when I use products in real } \\
\text { life }\end{array}$ \\
\hline AUR3 & Augmented reality helps me to learn new information by matching with my life history \\
\hline
\end{tabular}

